\title{
ETICKÉ OTÁZKY V MUZEJNÍ DOKUMENTACI A PREZENTACI'
}

\section{JAN DOLÁK}

\section{ABSTRAKT/ABSTRACT:}

Současná muzeologie často řeší otázky spojení s etikou práce muzeí, včetně přijímání kodexů pro jednotlivé činnosti muzeí. Text komparativním přistupem rozebírá klíčové problémy, jako je respekt $\mathrm{k}$ přírodním i archeologickým lokalitám, etika práce restaurátora a preparátora, dokumentace negativních aspektů společnosti apod. Zvláštní pozornost je věnována sběru a prezentaci lidských ostatků, předmětům sakrální povahy, otázkám vlastnictví apod. Problematika sbírkotvorné činnosti muzeí někdy vede přímo $\mathrm{k}$ atakům na jejich existenci a podstatu. Druhá část článku řeší obecné trendy v etice a morálce muzejní práce, $s$ apelem na nutnost vyjednávání, někdy i s využitím př́istupů source community, guardianship, public participation, crowdsourcing či community curation.

\section{Ethical questions in museum documentation and presentation}

Current museology often deals with questions concerning the ethical aspects of museum work, including the implementation of codes for individual museum activities. The text analyses in a comparative way

1 Celý text je postaven na habilitační přednášce proslovené před vědeckou radou Filozofické fakulty Univerzity Komenského v Bratislavě dne 27. února 2020. Příspěvek pochopitelně na omezeném prostoru nemá ambice se dotknout naprosto všech etických otázek spojených s muzejnictvím a vůbec už ne je všechny vyřešit. Otevírá však velké množství dotčených problémů, snad těch nejdůležitějších, a nabízí jejich řešení. the key problems, such as respect towards natural and archaeological sites, ethics of restoration and preparation work, documentation of negative aspects of society, etc. Special attention is paid to the retrieval and presentation of human remains, religious items, ownership issues, etc. The problem of collection-building activity of museums sometimes directly leads to attacks on their existence and fundamental principles. The second part of the article deals with general trends in ethics and moral of the museum work, with accent on the necessity of negotiations, sometimes using the following approaches: source community, guardianship, public participation, crowdsourcing or community curation.

\section{KLÍČOVÁ SLOVA/KEYWORDS:}

muzeum - muzeologie - etika morálka - sbírky - prezentace Česko - Slovensko museum - museology - ethics moral - collections - presentation Czech Republic - Slovakia

Motto: Jednadvacáté století bude bud' etické, nebo nebude vůbec.

\section{Gilles Lipovetsky}

Etika je jedním z nejfrekventovanějších problémů dnešního muzejnictví i muzeologie ${ }^{2}$ a Etická

2 Ze široké monografické a sborníkové produkce jmenujme alespoň: EDSON, Gary. Museum Ethics.
https://doi.org/10.5817/MuB2020-2-3

komise (Etická rada - ETHCOM) Mezinárodní rady muzeí ICOM je považována za nejdůležitější komisi ICOM. Etický kodex $\mathrm{ICOM}^{3}$ je pevnou součástí práce muzejníků, stejně jako další etické kodexy (pro přírodovědná muzea, dokument o profesi konzervátora a restaurátora, etický kodex přátel muzeí apod.). Etické kodexy představují jisté protiváhy chart lidských práv, nebot jsou „chartami povinností“, byt právně nevymahatelnými. Muzejní sféru ovlivňují i kodexy oborů v muzeích pěstovaných. Např. Společnost amerických archeologů vydala svůj první etický kodex již v roce 1948, v USA dokonce existuje Institute of Museum Ethics. Ve slovenském

London: Routledge, 1997; MARSTINE, Janet, Alexander A. BAUER and Chelsea HAINES

(eds.). New Directions in Museum Ethics. London: Routlege, 2014; MURPHY, Bernice, L. Museums, Ethics and Cultural Heritage. London: Routledge, 2016. Recenzováno: SEARLE, Chloe. Museums,

Ethics and Cultural Heritage. Bernice L. Murphy ed. New York: Routledge, 2016. The New Zealand Journal of Public History [online]. 2016, roč. 4, č. 1 [cit. 2020-06-26]. Dostupný z www: $<$ https://www.waikato.ac.nz/_data/assets/ pdf file/0008/322289/NZJPH4-Searle2.pdf $>$. Dále pak některé zdroje dostupné na internetu: HATALA MATTHES, Erich. Why museums need their own ethics departments. Apollo: the International Art Magazine [online]. 4 September 2017 [cit. 2020-06-26]. Dostupný z www: $<$ https://www.apollo-magazine.com/whymuseums-need-their-own-ethics-departments/> Nebo: MARANDA, Lynn. Museum Ethics in the 21st Century: Museum Ethics Transforming into Another Dimension. In ICOFOM Study Series 45, 2017. In OpenEditions Journal [online]. [cit. 2020-06-26]. Dostupný z www: <https:// journals.openedition.org/iss/443>. Přímo vztahem kultury a etiky se zabýval i Albert Schweitzer. SCHWEITZER, Albert. Kultúra a etika. Bratislava: Slovenský spisovatel, 1986.

3 s kritikou Etického kodexu ICOM vystoupili např. manželé van Menschovi. MENSCH, Peter van a Léontine MEIJER-VAN MENSCH. New Trends in Museology. Celje: Museum of Recent History, 2011. 
a českém muzejním prostředí se také setkáváme s otevíráním specifických otázek muzejní etiky, ${ }^{4}$ většinou však spíše na pozadí jiných problémů než jako samostatné téma.

Co to vlastně etika je a čím se liší od morálky? Při pohledu do odborné literatury zjistíme, že existuje nepřeberné množství definicí etiky a jejího odlišení od morálky, včetně přístupu anglosaského, který považuje obojí za jedno a totéž. Nedomnívám se, že by muzeologie či muzejnictví musely za každou cenu přicházet $s$ vlastními definicemi těchto kategorií. Etika (z řeckého ethos mrav) je teorie morálky, zkoumá normy morálky. Etika je disciplínou praktické filozofie. Na rozdíl od morálky, která je blíže konkrétním pravidlům, se etika snaží najít společné a obecné základy, na nichž morálka stojí. ${ }^{5}$ Ve vztahu k práci muzeí, potažmo k užívání dědictví, můžeme hovořit o aplikované etice.

Ignorace zdánlivě abstraktních problémů se projevuje nahromaděním nedorozumění uvnitř oboru i mezi muzei a veřejností. Výrok Lipovetského, uvedený jako motto tohoto textu, ale i názory mnoha dalších podobně uvažujících myslitelů, můžeme chápat jako varování, že nedostatek etiky ohrožuje přežití společnosti. Ǩada filozofů se domnívá, že žijeme v době absence odpovědných politických, ekonomických a kulturních elit, což je zřejmě pravda, jedná se však o téma výrazně přesahující rámec tohoto textu. Současná etika třetího typu ${ }^{6}$ upřednostňuje prioritu

4 KALISKÝ, Ján (ed.). Dobro a zlo alebo o morálke. Banská Bystrica: Univerzita Mateja Bela v Banskej Bystrici, 2013; Etika a tradiční lidová kultura. Strážnice: Ústav lidové kultury ve Strážnici, 1998.

5 Použitelné jsou i definice a pojetí autorit z frankofonního prostředí: DESVALÉES, André a François MAIRESSE. Key Concepts of Museology. Paris: Armand Colin, 2010, s. 32-34.

6 Podle Lipovetského etika prošla třemi paradigmatickými stádii. 1. Náboženství. 2. subjektivních práv, chaotizace společnosti relativizuje význam budoucnosti, ale i minulosti, ${ }^{7}$ což se bytostně dotýká fungování memoriálních institucí. Zákonů je dost, spíše více než je třeba, ale hlavně, jejich význam se přeceňuje. O to více stoupá význam etických kodexů, které jsou stále naléhavější. Čím se muzejnictví, potažmo muzeologie, $v$ oblasti etiky zabývají?

\section{ETIKA A MUZEJNÍ PRAXE}

\section{Respekt}

Klíčovým problémem je etika šetrného zasahování do původních skutečností (přírodní lokality, archeologická naleziště apod.). Nutný je i respekt ke zvířecím ostatkům, náležitá péče o zvířata držená v zajetí apod.

\section{Etika konzervátora, restaurátora a preparátora}

Nutný je respekt, nižší míra „kreativnosti“ a jistá pokora ke sbírkovému předmětu.

Jinými slovy, pokud nemáme perfektní znalost, jak např. obraz či ostrostřelecký terč původně vypadaly, není možné je „dotvářet“ podle vlastní fantazie restaurátora. Zásah do autenticity předmětu je nezbytný, ale měl by být co nejmenší. Čeští konzervátoři užívají pojem „zachování komplexní hodnoty". ${ }^{8}$ Jistěže do těchto

Sekularizovaná, laická etika, pro kterou jsou charakteristické odříkání a obět, vědomí morální povinnosti (18. století - 1950). 3. Současná etika třetího typu, zdůrazňující práva jedince, provázená ztrátou morální odpovědnosti a oslabením ochoty k oběti a sebeodříkání.

7 Na muzejní prostředí částečně aplikuji názory brněnského docenta Radima Brázdy. BRÁZDA, Radim. Srovnávací etika. Praha: Koniash Latin Press, 2002.

8 Za negativní příklad můžeme označit dřevěnou truhlu na oděvy v jednom muzeu v Žilinském kraji, na jejíž víko z vnitřní strany si slovenská žena poznamenávala významné události ve svém životě (např. narození dítěte). Tyto nápisy byly při konzervátorském zásahu pečlivě odstraněny. Jedná se nejen o porušení etických principů, ale částečně i o nepochopení vlastního smyslu sbírkotvorné činnosti muzea. procesů zasahují i kurátoři, správci či majitelé předmětů.

„Dobro“ versus „Zlo“

Častým jevem je fakt, že jednotlivci i celá společnost se snaží být představováni poněkud lepší, než tomu v minulosti bylo. Proto i v muzeích, představujících jakýsi národní (potažmo regionální či městský) „kánon“, jako by tomu mělo být obdobně. Zajímavý př́iklad uvádějí manželé van Menschovi ${ }^{9}$ $\mathrm{z}$ nizozemského prostředí, kde ve městě Apeldoorn v roce 2009 došlo k pokusu automobilem značky Suzuki usmrtit příslušníky královské rodiny. Akvizice vraku auta místním muzeem vyvolala ostrou celonárodní diskusi, v níž vystupovali především politici, ale téměř vůbec ne muzejní profesionálové. Muzeum bylo obviňováno $\mathrm{z}$ antisociálnosti. Př́ibuzní řidiče onoho auta soudně prosadili zničení automobilu. Jedná se o zásadní nepochopení muzejní dokumentace. Neexistuje obecně přijímaná definice muzea, která by upřednostňovala dokumentaci pouze pozitivních skutečností. Proto je správné, že se v muzeích nacházejí i busty diktátorů, hákové křiže apod. Netvrdím, že onen zmíněný automobil v muzeu být musí, ale $\mathrm{v}$ každém př́ípadě zde být může.

Domnívám se, že výše zmíněné principy $\mathrm{z}$ hlediska etického $\mathrm{v}$ našich muzeích většinově fungují. U dalších principů však můžeme nalézt větší tápání.

\section{Sběr, tezaurace a prezentace} lidských ostatků

\section{A. Kosti}

Pro řadu oborů (antropologie, archeologie apod.) se jedná

\footnotetext{
9 MENSCH, Peter van a Léontine MEIJER-VAN MENSCH. New Trends in Museology. Celje: Museum of Recent History, 2011.
} 
o základní materiál pro zkoumání minulosti a v našem kulturním okruhu jsou často vystavovány. O nutnosti pietního vztahu $\mathrm{k}$ těmto ostatkům není sporu ani pochybností. Přístupy k lidským kostem však mohou být velmi rozdílné. Existují i velmi radikální postoje, podle kterých by v muzeích žádné lidské ostatky být neměly. Kostnice v Sedlci u Kutné Hory se nedávno stala předmětem pozornosti americké stanice CNN, která vybavení tohoto římskokatolického kostela označila výrazem ,jen pro odvážné“. Jedná se o instalaci již z 19. století a o hluboké víře kutnohorských občanů netřeba pochybovat. Návštěvníci sem však přicházejí s podivnými představami, zejména co se týče pořizování selfie fotografií. Na sociálních sítích pak předváděli svoje olizování lebky, strkání prstů do očních důlků, hlazení lebek, aranžování kostí, focení se sekerami, meči a dokonce využívali prostoru kostnice ke cvičení jógy nebo prodeji různých satanistických předmětů. Vedení farnosti rozhodlo správně o redukci možnosti fotografování. ${ }^{10}$ Nevhodné chování návštěvníků však nemůže zpochybňovat samotné předvádění tohoto typu dědictví. Je třeba připomenout, že rozsáhlá a vcelku mladá americká města nikdy neměla takový problém s pochováváním zemřelých osob jako tradiční středověká města ve střední Evropě. Co se může jevit cizí v kultuře jedné (americké zpravodajské televizi), může být přijímáno zcela bez problémů v kultuře jiné.

Vztah k lidským ostatkům však může být rozdílný nejen $\mathrm{v}$ různých regionech, ale i v rámci jednoho regionu, ale jiného kulturního okruhu. Např. některé prvky pohřebního ritu jsou v židovské komunitě jiné než u křestanů. Židé

10 Za poskytnutí doplňujících informací děkuji Mgr. Radce Krejčí z místní farnosti. bývali pochováni ve stejném oděvu a ve stejné rakvi, a to bez ozdob, proto současná židovská komunita je velmi citlivá na zasahování do bývalých židovských hřbitovů, respektive na archeologický výzkum těchto lokalit. ${ }^{11}$ Řešení by proto mělo směřovat spíše $\mathrm{k}$ archeologickému dohledu než přímo výzkumu.

\section{B. Tetované lidské kůže}

Tento problém se týká především Maorů, ale nejen jich. Novozélandští kolegové vyvíjejí velký tlak na repatriaci těchto ostatků rozptýlených po Evropě a severní Americe. Také Národní muzeum v Praze má ve svých sbírkách tetovanou lidskou kůži z oblasti Mongolska. V tomto případě je třeba zvážit a posoudit nepochybnou dokumentační hodnotu objektu na straně jedné a vhodnost a způsob případné prezentace na straně druhé.

\section{Intimní části těla}

Docentka Petra Šobáňová ${ }^{12}$ před nedávnem připomněla osudy Afričanky Saartjie Baartmanové, která zemřela roku 1815 ve věku cca 25 let v Pařízii. Tato žena s výraznou steatopygií (zbytnění hýždí) byla předváděna v Londýně za 2 šilinky, pak prodána do francouzského zvěřince a ukazována spolu s medvědy a tygry, byla nucena k prostituci a její genitálie byly připodobňovány $\mathrm{k}$ opičím. Na jejím těle byla dokazována údajná rasová podřadnost Afričanů. Ostatky Saartjie Baartmanová se

\footnotetext{
11 V roce 2000 se konaly rozsáhlé stavební práce ve Vladislavově ulici v Praze, kde se v minulosti nacházel židovský hřbitov. Archeologický výzkum vyvolal domácí i mezinárodní kritiku. Více: DRAGOUN, Zdeněk. Památkový zákon a případ židovského hřbitova v Praze 1 - Vladislavově ulici - The Monuments law and the case of the Jewish cemetery in Vladislavova ul., Prague. Archeologické rozhledy, 2000, roč. 52, s. 447-452.

12 ŠOBÁŇOVÁ, Petra. Kritické teorie muzea podnět k reflexi. Muzeum: muzejní a vlastivědná práce, 2012, roč. 50, č. 2, s. 26-38.
}

staly předmětem jistého napětí mezi Francií a Jihoafrickou republikou ${ }^{13}$ a do Afriky byly navráceny až v roce 2002. Z hlediska dokumentačního mohlo jít o zajímavý materiál - po stránce antropologické či kulturní - ale na první pohled narážíme na zcela zásadní bariéry z hlediska etiky. V tomto případě použití vhodných dokumentačních metod (fotodokumentace, pořízení substitutů) nahrazujících originál je zcela dostačující.

\section{Sběr a prezentace předmětů sakrální povahy, zejména cizích kultur}

Našli bychom bezpočet příkladi̊ naprosto rozdílného chápání, pojetí a případné prezentace předmětů duchovní povahy, zejména $\mathrm{v}$ neevropském prostředí. Ale můžeme najít i př́íklady nám regionálně bližší. Nejednotný názor je např. uvnitř židovské komunity ohledně nálezů z geníz. V judaismu je náboženská povinnost uchovat vše co obsahuje jedno z Božích jmen (texty, ale třeba i liturgické předměty) a tyto genízy bývaly ukládány v základech synagog, na zvláštních místech hřbitovi̊ apod. Není pochyb, že jde o cenné prameny pro historické bádání. $O$ vhodnosti nakládání s těmito předměty, a to včetně prezentace, však musí rozhodnout židovská komunita sama.

\section{Otázky vlastnických vztahů (restituce, repatriace)}

Návrat původním majitelům lze chápat i jako etický závazek, což se netýká jen vztahu bývalá kolonie - bývalý kolonizátor. Jedná se o závazek i uvnitř našeho kontinentu, mám na mysli rozpad habsburské ř́íse, přesuny dědictví v době 2 . světové války,

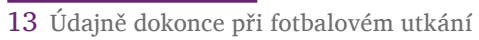
reprezentačních týmů obou zemí jihoafričtí fanoušci skandovali: „Vratte nám Sáru“.
} 
rozpad východního bloku a s tím spojený rozpad Československa či Jugoslávie apod. Dědictví tak někdy neplní svoji základní úlohu, být prostředkem k poznání (tedy pochopení) své vlastní kultury, ale i kultur ,jiných“. Dědictví nás $\mathrm{v}$ těchto případech spíše rozděluje. ${ }^{14}$ Nabízení tzv. „vizuální repatriace“, tj. poskytnutí předmětu původním majitelům nikoli přímo, ale pomocí nejmodernější techniky, ve většině případů neuspokojuje. Těmito otázkami se zabývalo i jednání komise ICOFOM v čínské Šanghaji. ${ }^{15}$

\section{Ataky na existenci muzeí jako takových}

K jakým závěrům pak společnost, někdy dokonce i odborná společnost, dochází? Muzeum je některými teoretiky chápáno jako predátor, který vytrhuje předměty (napřr. etnologické či archeologické povahy) z pưvodních nalezišt, z původních kultur, převáží jinam a zde je dekontextualizuje. Těmto otázkám bylo věnováno zasedání komise ICOFOM v italském Milánu v rámci Generální konference ICOM $\mathrm{v}$ roce $2016^{16} \mathrm{i}$ následná polemika. ${ }^{17}$ Zásadní napětí je pocitováno

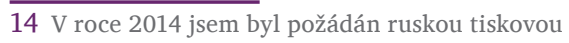
agenturou RIA NOVOSTI o stanovisko, komu vrátit sbírkové předměty z období říše Skythů zapůjčené z krymských muzeí na výstavu do Nizozemí, zda na Krym či Ukrajině. Zde existují různé úhly pohledu. Ten právní akcentuje, že smlouva o zápůjčce byla podepsána mezi Nizozemím a Ukrajinou. Z muzeologického hlediska je však situace naprosto jasná. Počátky archeologického zkoumání pobytu Skythů na území Krymu (zhruba 7.-3. století před naším letopočtem) můžeme datovat ještě do carských dob a nikdy nešlo o výzkum nějak vpravdě revoluční $\mathrm{z}$ hlediska politického nazírání na věc. Proto předměty zapůjčené do Nizozemí tvoří organickou součást sbírek krymských muzeí a v nějakém kyjevském muzeu by byly více méně solitéry.

15 DOLÁK, Jan. On the issues of deaccessioning and repatriation of museum collections. In Deaccession and Return of Cultural Heritage A New global Ethics. ICOFOM Study Series 39. Shanghai: Zhejiang provincial museum, 2010, s. $43-50$.

16 MARANDA, Lynn a Bruno Brulon SOARES (eds.). The Predatory Museum. ICOFOM Study Series 45, 2017.

17 DOLÁK, Jan. Teoretická podstata muzeologie. Brno: Technické muzeum v Brně, 2019,

s. 133-135. především na ose bývalá kolonie bývalý kolonizátor či uvnitř států, kde nově příchozí etnikum ovládlo to dřive usazené (Kanada, USA apod.), ale i v našem prostoru najdeme názory podobného druhu. Český archeolog Slavomil Vencl, zneklidněný ilegálním rabováním archeologických lokalit, tvrdí, opírajíc se o anglosaské zdroje, že „skutečnými lupiči archeologického dědictví jsou muzea a sběratelé, kteři svými nálezy vlastně inspirují a financují nelegální vykrádání nalezišt" ${ }^{\prime 18}$ Znepokojení českého archeologa je pochopitelné, avšak neústí ke zcela racionálním závěrům. Restaurace pořádající zvěřinové hody také přece nezodpovídá za prípadné pytláctví, nábytkářská firma neodpovídá za ilegální drancování lesů. Nebo snad mají předměty získané nelegálním výzkumem „povinně“ zmizet ze zřetele muzeí? Řešení spatřuji $\mathrm{v}$ rovině muzeologicko-právní. Dekontextualizovaný předmět bez průvodní dokumentace má nevelkou cenu, přejímání předmětů neznámého původu či pocházející z nelegálních zdrojů je zakázáno zákonem. Pokud muzea budou nikoli „sběratelé předmětů“, ale „tvưrci programově vytvářené sbírky“, budou nález nejasného původu přijímat jen ve výjimečných případech a ten tím ztratí finanční atraktivitu pro případné ilegální hledače pokladů. Sbírky nejasného původu, napřr. ikony $\mathrm{z}$ východu, se dostávají do muzeí jen výjimečně (např̀. Múzeum a Kultúrne centrum južného Zemplína v Trebišove). Fakticky však, přestože neznáme ani stát, ze kterého pocházejí, je původce zřejmý - Celní úřad Slovenské republiky. ${ }^{19}$ Obdobným

\footnotetext{
18 VENCL, Slavomil. Archeologie a etika. Archeologické rozhledy, 2000, roč. LII, s. 438. Vencl vyčítal Slovenskému národnému múzeu v Bratislavě, že pod kurátorstvím Lva Zachara uspořádalo v roce 1993 výstavu „Poklady Pohanská" s použitím depotů, které předtím SNM nakoupilo od hledačů pokladů.

19 Michaela Klácíková ve své bakalářské práci píše: „Zaujímavým príkladom zbierkotvornej

činnosti múzea je získanie 17 ikon a 14 olejomalieb
}

způsobem rozšířilo své sbírky v roce 1997 o ikony též Vlastivědné muzeum v Olomouci.

\section{OBECNÉ TRENDY V ETICE A MORÁLCE MUZEJNÍ PRÁCE, VÝVOJ A TRENDY}

Většina základních principů etického chování muzeí zůstává nadále v platnosti. Sbírky musí být získávány striktně legálně, materiál včetně evidence musí být volně přístupný badatelům. Přitom je nutné zachovávat důvěrnost smluvních ujednání. Muzea musí být mimořádně obezřetná k obchodu se starožitnostmi a chráněnými přírodninami. ${ }^{20}$ $\mathrm{Z}$ pozic etiky je třeba řešit případný stř̌et zájmů, tedy kurátor nesmí sbírat soukromě to, co má za úkol obhospodařovat jako muzejní pracovník. Byli jsme svědky i tzv. kontraktní archeologie (archeologie pro peníze). Praktickým problémem bývá mimoběžnost záměrů archeologa (věda, péče o dědictví) a stavebníka $\mathrm{v}$ případě záchranných výzkumů.

Velkým tématem dnešních dnů je etické vypořádání se s rozdílnými přístupy $\mathrm{k}$ dědictví nejrůznějších národů, etnických či náboženských skupin. Pravdu má německý filozof Axel Honneth, který píše: „Teoretickým východiskem etiky je dnes idea morálního zohlednění zvláštního, heterogenního." ${ }^{21}$ Zde je při práci muzeí nutno apelovat na nekonfrontační způsob jednání umožňující určitý nadhled s akcentem na vzájemnou důvěru. $\mathrm{V}$ př́ípadě konfliktu je

\footnotetext{
v roku 1998, ktoré múzeum získalo vd’aka colnému úradu v Čiernej nad Tisou." KLÁCIKOVÁ, Michaela. Zbierkotvorná činnost' Múzea a Kultúrneho centra južného Zemplína v Trebišove. Bratislava: Univerzita Komenského v Bratislave, Filozofická fakulta, Katedra etnológie a muzeológie, 2020, s. 15. Bakalárska práca.

20 Podle našich informací se v českých muzejních obchodech objevily geologické nálezy z Boskovické brázdy, které jen stěží mohly být získány legálně.

21 HONNETH, Axel. Sociální filozofie a postmoderní etika. Praha: Filosofia, 1996, s. 92.
} 
nutné vyjednávání. V zahraniční literatuře se často setkáváme s (proti)póly: source community versus contemporary community, opatrovnictví (guardianship) versus vlastnictví, píše se o public participation, crowdsourcing, community curation apod. Může docházet ke konfliktu vzdělání kurátora na straně jedné a cítěním (potřebami) komunity na straně druhé. Problémem může být už pouze vyrábění kopií pro komerční účely.

Naskýtá se však obecně laděná otázka. Kdo je odpovědný hovořit za komunitu, které příklady (dokumentace a užívání) jsou akceptovatelné jako reprezentativní? Mají komunity vždy pravdu, respektive jejich mluvčí a kdo je tím správným mluvčím? Migrantské skupiny tendují dávat větší význam některým jiným „ideálně typickým konstruktům identity“ než tomu je v zemi jejich původu. Jinými slovy, Afričan dlouhodobě žijící třeba v Londýně může význam a užívání afrických artefaktů podceňovat, ale spíše přeceňovat, protože toto dědictví již delší dobu „nežije“. Pokud se náš hypotetický Afričan vrátí do místa svého původu, umožní mu jeho znalost „neafrického“ prostředí, hodnot, morálky, jeho vzdělání v rámci jiného kulturního modelu apod., lepší reflexi svého vlastního dědictví?

Muzea tedy musí být otevřena odlišným naracím a životním cílům „jiných“, ale na druhé straně nesmí ztrácet solidarizující sílu kolektivního utváření identity „nás“. Pojem identita je nejasný a lidé dávno nežijí v př́írodním stavu či podle jednolitých tradic. Hovoří se proto o skladebné identitě, patchworkidentity, die Bastel Biographie, průběžné identitě apod. Bohužel, často se identita zaměňuje s pouhým image. Pravdu tedy má i německý filozof Jürgen Habermas, podle kterého „v moderních podmínkách se individuální životní ideály rozcházejí $v$ takové míře, že etika nemůže normativně doporučit určité hodnoty, nýbrž jen zvláštní proceduru řešení“. ${ }^{22}$

Je iluzorní se domnívat, že větší poznání lidí se navzájem automaticky vede $\mathrm{k}$ větší lásce a porozumění mezi lidmi. Kulturní pluralismus vyjadřovaný heslem ,jinakost obohacuje“, jakoby bez konce, nezaručuje větší solidaritu a toleranci mezi lidmi. Právě prosazování relativismu všeho kolem nás se může hroutit do symptomů xenofobie, nacionalismu či přímo rasismu.

Naskýtá se však zásadní otázka. Lze mravní chování vztahovat k univerzálně použitelným principům? V obecnější rovině s pokusy najít nějakou univerzální „hlubinnou“ strukturu morálky úspěšně polemizuje Radim Brázda. ${ }^{23}$ Křivda je to, když může být normativně prokázáno narušení oprávněných nároků člověka. Ale kdy se tak děje? Od společnosti se nyní požaduje nejen rozumné uznání práv každého na svobodu vyznání, práv politických názorů a na soukromí, ale také povinné uznání rovnocennosti, jak by to nebylo zvláštní, dobra a zla, rozdílných ve svém smyslu pojmů. Podobný rozpad tradičních hodnot „seshora“ má nejen negativní následky pro společnost, ale je také od základi̊ antidemokratický, protože je realizován na základě abstraktních, teoretických idejí, proti vůli společenské většiny, která neschvaluje probíhající změny a navrhované revize.

Spory nevznikají při respektování jednoduchý pravidel -

křestanského nekrad', nezabij, ale

22 Převzato z: HONNETH, Axel. Sociální filozofie a postmoderní etika. Praha: Filosofia, 1996, s. 99. 23 BRÁZDA, Radim. Srovnávací etika. Praha: Koniash Latin Press, 2002. Také francouzský sociolog Pierre Bourdieu byl nedůvěřivý je všem univerzálním hodnotám, které považoval za hodnoty pouze univerzalizované, tedy podezřelé. při nemožnosti jejich jednotného výkladu. Už při starozákonním „nezabiješ“ nevíme, zda se vztahovalo pouze dovnitř na členy židovské komunity či na širší spektrum osob.

V celkových přístupech ke kulturnímu dědictví můžeme najít dva základní, často prolínající se trendy, „,atomistický“

a „univerzální“. Jedná se o jakousi jednotu bez sjednocení, při které dochází ke ztrátě kontroly obsahu.

V prvně jmenovaném slýcháme „Všechno dědictví musí být zachráněno a dále používáno a praktikováno“. Radim Brázda uvádí zajímavý příklad francouzské etnoložky, která litovala, že angličtí kolonialisté vyhubili zavedením preventivního očkování proti neštovicím prastarý kult Sittala Devi: kult bohů, $\mathrm{k}$ nimž směřovaly modlitby za odvrácení neštovic. „Bohužel“, začalo přežívat více lidí. ${ }^{24}$ Sám jsem upozornil na rozhořčení norských ekomuzeologů, kteří kritizovali fakt, že středověce žijící čínská vesnice si po př́livu turistů opravila své domy nepůvodním materiálem a zavedla elektřinu, vodovodní řád a „dokonce“ postavila školu. Norové litovali, že mladé ženy navštěvují školu místo toho, aby se věnovaly tkaní tradičních výšivek. ${ }^{25} \mathrm{Na}$ tomto místě je nutné zcela rozhodně vymezit, že žádné dědictví není chráněno pro nějaké abstraktní hodnoty, pro přednostní „odkaz budoucím generacím“ a vůbec ne pro pobavení (zahraničních) turistů. Dědictví chráníme a využíváme pro současnou potřebu lidstva.

Zastánci druhého směru se snaží vytvářet jakési seznamy „správných“ a především „univerzálních“ hodnot, což je

\footnotetext{
24 BRÁZDA, Radim. Srovnávací etika. Praha: Koniash Latin Press, 2002, s. 127.

25 DOLÁK, Jan. Sběratelství a sbírkotvorná činnost muzé́. Bratislava: Univerzita Komenského v Bratislave, 2018, s. 45-46.
} 
přístup různých mezinárodních organizací (UNESCO) s jistou tendencí k megalomanským chimérám. Jedná se např̀. o projekty Global Ethics for a New Global Order, Universal Ethics Project či Světový étos pro politiku a hospodářství. ${ }^{26}$

V metodologii humanitních věd hraje významnou roli kritika pramenů a jejich interpretace, což není úkol jednoduchý a pro neškoleného člověka většinou nezvládnutelný. Popis a interpretace předchozích událostí, což je úkol i muzeí, je nyní komplikován širokou snahou o destrukci stávajících narací, v nejednom př́ípadě aktivovanou i politickými záměry. Jako bychom za hlavní účel současné narace historiků, tedy i muzejní narace, považovali maximální snahu nenajít žádný archimédovský bod. Rozšiřování řečiště diskurzivní delty ${ }^{27}$ však paralyzuje přesvědčivé výkony. Současné „sochoborectví“ má vlastně značný vliv i na práci muzeí. Čí socha může stát na náměstí a čí být umístěna „pouze“ v muzeu, dokonce jen s vysvětlující tabulkou? Posuzování událostí a osobností v minulosti prizmatem dnešních hodnot je nejen ahistorické, ale i směšné. Domnívám se, že sochu si zaslouží ten, který se v dané době projevoval v něčem „normálně“, ale v něčem jiném byl zcela výjimečný. Byl tedy reprezentantem britského imperialismu, ale měl zásadní význam pro vítězství nad fašismem - Winston Churchill. Projevoval se antisemitsky, ale měl zásadní význam pro etablování slovenštiny - L'udovít Štúr. Je třeba si uvědomit, že řada soudobých koncepcí (např. rovnost mužů a žen) je poměrně mladá. Pokud bychom chtěli

\footnotetext{
26 Problematikou univerzálních hodnot se zabývám v: DOLÁK, Jan. Teoretická podstata muzeologie. Brno: Technické muzeum v Brně, 2019, s. 97-98.

27 Výrazy „,archimédovský bod“ a „řečiště diskurzivní delty“ jsou převzaty od R. Brázdy.
}

současné pojetí rovnoprávnosti obou pohlaví aplikovat na minulost, nezůstanou na našich náměstích ani sochy M. Jana Husa. Muzea by v dnešní rozklížené době měla být ostrůvky plastického a trpělivého vysvětlování minulých časů. To bez fundovaného, politicky a ideologicky neutrálního přístupu realizovat nelze. Jedná se o jeden z nejvýznamnějších etických imperativů dnešní práce muzeí.

\section{SEZNAM POUŽITÝCH ZDROJŮ:}

BRÁZDA, Radim. Srovnávací etika. Praha: Koniash Latin Press, 2002

ISBN 80-85917-86-6.

DESVALÉES, André a François MAIRESSE. Key Concepts of Museology. Paris: Armand Colin, 2010. ISBN 978-2-200-25398-1.

DOLÁK, Jan. On the issues of deaccessioning and repatriation of museum collections. In Deaccession and Return of Cultural Heritage - A New global Ethics. ICOFOM Study Series 39. Shanghai: Zhejiang provincial museum, 2010, s 43-50. ISBN 978-988-18325-6-6.

DOLÁK, Jan. Sběratelství a sbírkotvorná činnost muzeí. Bratislava: Univerzita Komenského v Bratislave, 2018. ISBN 978-80-223-4553-8.

DOLÁK, Jan. Teoretická podstata muzeologie. Brno: Technické muzeum v Brně, 2019. ISBN 978-80-87896-67-9.

DRAGOUN, Zdeněk. Památkový zákon a případ židovského hřbitova v Praze 1 Vladislavově ulici - The monuments law and the case of the Jewish cemetery in Vladislavova ul., Prague. Archeologické rozhledy, 2000, roč. 52, s. 447-452. ISSN 2570-9151.

EDSON, Gary. Museum Ethics. London: Routledge, 1997. ISBN 978-0-415-15290-7.

Etika a tradiční lidová kultura. Strážnice: Ústav lidové kultury ve Strážnici, 1998. ISBN 80-86156-17-6.

HATALA MATTHES, Erich. Why museums need their own ethics departments. Apollo: the International Art Magazine [online]. 4 September 2017 [cit. 2020-06-26]. Dostupný z www: <https://www.apollo-magazine. com/why-museums-need-their-ownethics-departments/>.
HONNETH, Axel. Sociální filozofie a postmoderní etika. Praha: Filosofia, 1996, s. 92. ISBN 80-7007-082-X.

KALISKÝ, Ján (ed.). Dobro a zlo alebo o morálke. Banská Bystrica: Univerzita Mateja Bela v Banskej Bystrici, 2013. ISBN 978-80-557-0538-5.

KLÁCIKOVÁ, Michaela. Zbierkotvorná činnost' Múzíea a Kultúrneho centra južného Zemplína v Trebišove. Bratislava: Univerzita Komenského v Bratislave, Filozofická fakulta, Katedra etnológie a muzeológie, 2020, s. 41. Bakalárska práca. Školitel: PhDr. Jan Dolák, Ph.D.

MARANDA, Lynn. Museum Ethics in the 21st Century: Museum Ethics Transforming into Another Dimension. In ICOFOM Study Series 45, 2017. In OpenEditions Journal [online]. [cit. 2020-06-26]. Dostupný z www: < https://journals. openedition.org/iss/443>. https://doi.org/10.4000/iss.290

MARANDA, Lynn a Bruno Brulon SOARES (eds.). The Predatory Museum. ICOFOM Study Series 45, 2017.

ISBN 978-92-9012-429-0.

MARSTINE, Janet, Alexander A. BAUER and Chelsea HAINES (eds.). New Directions in Museum Ethics. London: Routlege, 2014. ISBN 978-113-8841182-6.

MENSCH, Peter van a Léontine MEIJERVAN MENSCH. New Trends in Museology. Celje: Museum of Recent History, 2011. ISBN 978-961-6339-29-2.

MURPHY, Bernice, L. Museums, Ethics and Cultural Heritage. London: Routledge, 2016. ISBN 978-1-138-67632-9.

SEARLE, Chloe. Museums, Ethics and Cultural Heritage. Bernice L. Murphy ed. New York: Routledge, 2016. The New Zealand Journal of Public History [online]. 2016, roč. 4, č. 1 [cit. 2020-06-26]. Dostupný z www: $<$ https://www.waikato.ac.nz/__data/ assets/pdf_file/0008/322289/NZJPH4Searle2.pdf $>$. Review. Museum, ethics and cultural heritage. ISSN 2253-153X.

SCHWEITZER, Albert. Kultúra a etika. Bratislava: Slovenský spisovatel, 1986.

ŠOBÁŇOVÁ, Petra. Kritické teorie muzea podnět k reflexi. Muzeum: muzejní a vlastivědná práce, 2012, roč. 50, č. 2 , s. 26-38. ISSN 1803-0386.

VENCL, Slavomil. Archeologie a etika. Archeologické rozhledy, 2000, roč. LII, s. 428-441. ISSN 2570-9151. 


\section{JAN DOLÁK}

Katedra etnológie a muzeológie, Univerzita Komenského v Bratislave, Slovenská republika jan.dolak@uniba.sk

Jan Dolák přednáší muzeologii na Univerzitě Komenského v Bratislavě (Slovensko). Zaměřuje se především na teoretickou muzeologii, sbírkotvornou a výstavní činnost muzeí, částečně na muzejní management a marketing. Bývalý předseda Asociace muzeí a galerií, dnes předseda muzeologické komise AMG. Dlouhodobě působí ve vedení mezinárodní komise ICOFOM. Autor více jak sto prací publikovaných v sedmi jazycích.

Jan Dolák teaches museology at the Comenius University in Bratislava (Slovakia). His main focus lies on theoretical museology, collectionbuilding and exhibition-making activity of museums, partly also on museum management and marketing. Formerly, he was Chairman of the Association of Museums and Galleries, today he is Chairman of the Museological Commission of AMG. He is long-acting leading member of the international ICOFOM commission and author of more than hundred works published in seven languages. 